University of Nebraska - Lincoln

DigitalCommons@University of Nebraska - Lincoln

6-2009

\title{
Redescription of the Frog Bladder Fluke Gorgoderina attenuata from the Northern Leopard Frog, Rana pipiens
}

\author{
Matthew G. Bolek \\ Oklahoma State University, bolek@okstate.edu \\ Scott D. Snyder \\ University of Nebraska at Omaha, sdsnyder@mail.unomaha.edu \\ John J. Janovy Jr. \\ University of Nebraska - Lincoln, jjanovy1@unl.edu
}

Follow this and additional works at: https://digitalcommons.unl.edu/bioscijanovy

Part of the Parasitology Commons

Bolek, Matthew G.; Snyder, Scott D.; and Janovy, John J. Jr., "Redescription of the Frog Bladder Fluke Gorgoderina attenuata from the Northern Leopard Frog, Rana pipiens" (2009). John Janovy Publications. 59.

https://digitalcommons.unl.edu/bioscijanovy/59

This Article is brought to you for free and open access by the Papers in the Biological Sciences at DigitalCommons@University of Nebraska - Lincoln. It has been accepted for inclusion in John Janovy Publications by an authorized administrator of DigitalCommons@University of Nebraska - Lincoln. 


\title{
REDESCRIPTION OF THE FROG BLADDER FLUKE GORGODERINA ATTENUATA FROM THE NORTHERN LEOPARD FROG, RANA PIPIENS
}

\author{
Matthew G. Bolek ${ }^{\star} \dagger$, Scott D. Snyder ${ }^{\star} \neq$, and John Janovy, Jr. \\ School of Biological Sciences, University of Nebraska_Lincoln, Lincoln, Nebraska 68588. e-mail: bolek@okstate.edu or \\ sdsnyder@mail.unomaha.edu
}

\begin{abstract}
Morphological characters used to differentiate North American bladder flukes, Gorgoderina spp., are problematic and different authors use different morphological characteristics for distinguishing species. More importantly, no type specimens exist for 4 of the 12 North American species infecting anuran and caudatan hosts. A redescription of Gorgoderina attenuata (Stafford, 1902) Stafford, 1905 is based on new collections from 6 species of anurans from Arkansas, Nebraska, New York, and Wisconsin. Morphological comparisons between gravid G. attenuata recovered from bullfrogs and northern leopard frogs indicated statistically significant differences in 11 of 28 morphological characters examined. However, there was overlap among all of these characters, and it is unclear whether these morphological types represent host-induced morphological changes in worm morphology or cryptic species. Based on our findings, we suggest that morphological and molecular data from G. attenuata-like worms recovered from the other 23 definitive hosts reported for $G$. attenuata need to be collected to resolve this issue.
\end{abstract}

There are more than 50 species of Gorgoderina Looss, 1902 amphibian bladder flukes found worldwide. Twelve species have been described from anuran and caudatan hosts from Canada and the United States (see Mata-López et al., 2005; MataLópez 2006). Stafford (1902) described 3 species of Gorgodera Looss, 1899, now considered to be members of Gorgoderina: Gorgoderina attenuata (Stafford, 1902) Stafford, 1905, G. opaca, (Stafford, 1902) Stafford, 1905, and G. translucida (Stafford, 1902) Stafford, 1905; Stafford (1902) also reported on $G$. simplex (Looss, 1899) Looss, 1902 and Gorgodera amplicava Looss 1899 from anurans assumed to be collected in Toronto, Canada. None of these specimens was deposited in any museum. To our knowledge, no type specimens exist for $G$. attenuata or the other Gorgoderina spp. described or reported on by Stafford (1902) in the Harold W. Manter Laboratory (HWML) of Parasitology or the U.S. National Parasite Collection, and it is assumed that the types for these 4 North American species of Gorgoderina, including $G$. attenuata, have been lost or destroyed. Of the 4 species of Gorgoderina reported by Stafford (1902), G. attenuata is the most commonly reported bladder fluke in North and Central American anurans and caudatans and it has been reported from 24 amphibian and reptilian hosts (see Brooks, 1976; Mata-López et al., 2002; Bolek and Coggins, 2003; Mata-López and León-Règagnon, 2006; Bolek et al., 2009).

Stafford (1902) described G. attenuata from the green frog Rana virescens, which is currently a junior synonym of the southern leopard frog Rana sphenocephala Cope 1886. The range of the southern leopard frog does not extend into Canada and it is not clear what species of frog Stafford (1902) was dealing with (Lannoo, 2005). However, R. virescens has also been used as a synonym for the northern leopard frog Rana pipiens Schreber, 1782 (see Frost et al., 2006) in the older literature, and it is assumed that Stafford's G. attenuata was described from the northern leopard frog that occurs in Canada

Received 13 November 2008; revised 9 December 2008; accepted 9 January 2009.

* To whom correspondence should be addressed.

$\dagger$ Current Address: Department of Zoology, Oklahoma State University, Stillwater, Oklahoma, 74078.

$\ddagger$ Department of Biology, University of Nebraska at Omaha, Omaha, Nebraska 68182

DOI: $10.1645 / G E-1953.1$ (see Brooks, 1976). From Stafford's description, the type of locality for G. attenuata is also unclear. Stafford (1902) indicated that he collected G. translucida from Bufo lentiginosus (a junior synonym for Bufo americanus LeConte in Cuvier, 1831) and $R$. virescens, and gives Ashbridges Bay, Toronto, as the location for his collection of $B$. lentiginosus, but he provides no other localities for any of the other anurans that he examined. More problematic is the fact that Stafford's description of G. attenuata and the other 3 species of Gorgoderina are very poor and most morphological characters are omitted.

Due to Stafford's (1902) poor descriptions, morphological characters used to identify $G$. attenuata from the other 11 North American Gorgoderina spp. are problematic because different authors use different morphological characteristics in distinguishing among species (see Stafford, 1902; Cort, 1912; Olsen, 1937; Goodchild, 1950; Brooks, 1976; Mata-López et al., 2005). The defining characters in distinguishing G. attenuata from most other North American Gorgoderina spp. are the attenuated body and the large acetabulum diameter reported as the oral sucker to acetabulum ratio (OS). However, depending on the author, reports of this ratio differ from 1:2.1 to as large as 1:2.85-3.0 (Stafford, 1902; Cort, 1912; Olsen, 1937; Goodchild, 1950; Brooks, 1976; Mata-López et al., 2005). Finally, recent studies on the life cycle of $G$. attenuata by Bolek et al. (2009) indicate that the life cycle of $G$. attenuata from $\mathrm{Ne}$ braska differs among northern leopard frogs and bullfrogs Rana catesbeiana Shaw 1802 and from the original life cycle description of this species in green frogs Rana clamitans Latreille in Sonnini de Manoncourt and Latreille, 1801 and eastern newts Notophthalmus viridescens (Rafinesque, 1820) from Massachusetts (Rankin, 1939). These data suggest that G. attenuata from different hosts may represent distinct populations, or cryptic species. Taken together, Stafford's (1902) poor description, the questionable identity of the type host, and the lack of a type locality for $G$. attenuata, along with the discovery of life cycle variation by Bolek et al. (2009) warrant the redescription of $G$. attenuata. In this paper, we address these issues by (1) redescribing G. attenuata from 6 species of anurans from specimens collected from a variety of locations in North America and designating a neotype specimen of this species; and (2) comparing the morphology of $G$. attenuata-like worms that vary in their recruitment in northern leopard frogs and bullfrogs in Nebraska (Bolek et al., 2009). 


\section{MATERIALS AND METHODS}

Worms used for morphological analysis were collected from a number of frog and toad species and locations during 1996-2007 in Arkansas, Nebraska, New York, and Wisconsin. (See Bolek et al., 2009, for data on population structure among different anuran species.) These included 2 worms recovered from a southern leopard frog (Rana sphenocephalas) collected from a pond in Washington County, Arkansas $\left(35^{\circ} 46.979^{\prime},-94^{\circ} 14.687^{\prime}\right)$; 8 worms from northern leopard frogs (Rana pipiens), 1 worm from bullfrogs ( $R$. catesbeiana), and 1 worm from Woodhouse's toads (Bufo woodhousii, Girard 1854), all from Cedar Creek, Keith County, Nebraska $\left(41^{\circ} 11.194^{\prime},-101^{\circ} 21.820^{\prime}\right)$; 9 worms from bullfrogs from Breen's Flyway, Keith County, Nebraska $\left(41^{\circ} 10.914^{\prime},-101^{\circ} 21.654^{\prime}\right) ; 8$ worms from bullfrogs from Elk Creek, Lancaster County, Nebraska $\left(40^{\circ} 53.145^{\prime},-96^{\circ} 50.048^{\prime}\right)$; 1 worm from a plains leopard frog (Rana blairi, Mecham, Littlejohn, Oldham, Brown, and Brown, 1973) from Pawnee Lake, Lancaster County, Nebraska $\left(40^{\circ} 51.589^{\prime},-96^{\circ} 53.468^{\prime}\right) ; 1$ worm from a green frog (Rana clamitans) from Queechy Lake, Columbia County, New York (42 24.269', $-73^{\circ} 25.627^{\prime}$ ); and 2 worms from northern leopard frogs from Brookfield, Waukesha County, Wisconsin $\left(43^{\circ} 04.082^{\prime},-88^{\circ} 04.973^{\prime}\right)$. All worms that were used for the redescription were removed from the urinary bladders of anurans, relaxed in tap water, and fixed in alcoholformalin-acetic acid. Worms were stained with acetocarmine, dehydrated in a graded ethanol series, cleared in xylene, and mounted in Canada balsam. Additionally, to obtain a better geographical representation of G. attenuata, voucher specimens were borrowed from the HWML, University of Nebraska State Museum. Because not all worms borrowed from the HWML could be identified as G. attenuata, we only included 10 worms from a northern leopard frog from Nebraska (HWML 20123), 2 worms from a bullfrog from Nebraska (HWML 20121), and 1 worm from a green frog from Wisconsin (HWML 21344). Based on recent and past Gorgoderina spp. descriptions and redescriptions by Brooks (1976) and Mata-López et al. (2005), the following characters were in the descriptions: (1) body shape, length, and width; (2) forebody length and width at cecal bifurcation; (3) hindbody length and width at anterior testis; (4) oral sucker location, length, and width; (5) esophagus length and width; (6) acetabulum length and width; (7) oral sucker/acetabulum length and width ratio (OS/AC); (8) body width to acetabulum width ratio; (9) cecal length from posterior extremity; (10) testes morphology, location, and length and width; (11) seminal vesicle shape, position, and location; (12) genital pore location; (13) ovary morphology and location; (14) vitellaria number and location; (15) uterine loop distribution; and (16) egg length and width.

Student's 2-tailed $t$-test was used to compare morphological characteristics between $G$. attenuata collected from bullfrogs and northern leopard frogs. An approximate $t$ ' ${ }_{s}$-test was calculated when variances were heteroscedastic (Sokal and Rohlf, 1981). A drawing of a gravid worm from the bladder of a northern leopard frog was done with the aid of a camera lucida. In the redescription, ranges are presented, followed by means in parentheses.

\section{REDESCRIPTION}

\section{Gorgoderina attenuata (Stafford, 1902) Stafford, 1905 (Fig. 1)}

Diagnosis (based on 46 gravid specimens, from the urinary bladder of 6 species of anurans): Body spindle shaped, blunt anterior end, attenuated end; body length $1.28-5.55 \mathrm{~mm}$ (3.23). Forebody $0.20-1.00$ $\mathrm{mm}(0.53)$ long and $0.15-0.52 \mathrm{~mm}(0.26)$ wide at level of cecal bifurcation. Hindbody $0.19-4.03 \mathrm{~mm}$ (2.25) long and $0.25-0.61 \mathrm{~mm}(0.40)$ wide at widest part of hindbody. Oral sucker subterminal, spherical, 120-520 $\mu \mathrm{m}$ (273) long and 110-460 $\mu \mathrm{m}$ (248) wide. Pharynx absent. Esophagus straight or curved, thick walled, 80-180 $\mu \mathrm{m}$ (120) long, and 30-60 $\mu \mathrm{m}$ (41) wide at widest point. Ceca simple, initial portion wider and sometimes lobed; ceca ending at 5.6-12.0 (7.5\% of body length) $(\mathrm{n}=20)$ from posterior extremity. Acetabulum in anterior third of body; 390-940 $\mu \mathrm{m}$ (592) long by 350-900 $\mu \mathrm{m}$ (597) wide. Oral sucker/acetabulum length ratio $0.28-0.76(0.47)$; OS/AC width ratio $0.28-0.69$ (0.42). Ratio of body width to acetabulum width $0.41-0.96$ (0.68). Two testes, oval, sometimes irregular in shape in large individuals, positioned in tandem in midhindbody, anterior testis $40-600 \mu \mathrm{m}$ (373) long by 100-380 $\mu \mathrm{m}$ (232) wide, and posterior testis 90-980 $\mu \mathrm{m}$ (520) long (n

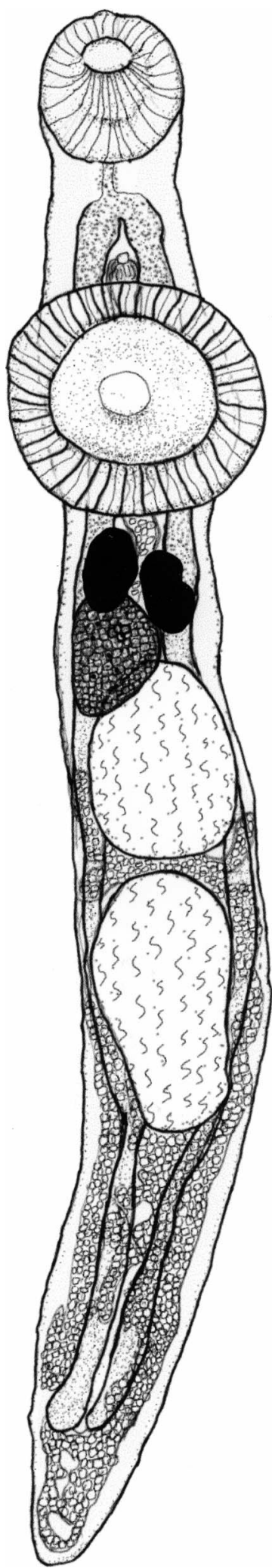

FIGURE 1. Line drawing of the neotype of G. attenuata (HWML 49008) from a northern leopard frog (R. pipiens) collected from Cedar Creek, Keith County, Nebraska. Scale bar $=1 \mathrm{~mm}$. 
TABLE I. Morphological characteristics of adult G. attenuata from bullfrogs and northern leopard frogs. Range and means (in parentheses) are given in $\mu \mathrm{m}$ unless otherwise noted.

\begin{tabular}{|c|c|c|c|c|}
\hline & $\begin{array}{l}\text { G. attenuata from bullfrogs } \\
\mathrm{n}=20 \\
\text { Range (mean) }\end{array}$ & $\begin{array}{l}\text { G. attenuata from northern leopard frogs } \\
\qquad \mathrm{n}=20 \\
\text { Range (mean) }\end{array}$ & $t$-Test & $P /=/$ \\
\hline Body length & $1.3-4.5 \mathrm{~mm}(2.9)$ & $2.2-5.0 \mathrm{~mm}(3.3)$ & -1.5 & 0.14 \\
\hline Body width & $0.25-0.56 \mathrm{~mm}(0.35)$ & $0.35-0.55 \mathrm{~mm}(0.44)$ & $-4.18 *$ & 0.0002 \\
\hline Forebody length & $0.20-0.61 \mathrm{~mm}(0.45)$ & $0.45-1.0 \mathrm{~mm}(0.60)$ & -3.50 & 0.001 \\
\hline Hind body width & $0.25-0.56 \mathrm{~mm}(0.35)$ & $0.35-0.55 \mathrm{~mm}(0.44)$ & $-4.18 *$ & 0.0002 \\
\hline Oral sucker length & $120-300(230)$ & $200-450(293)$ & -3.63 & 0.0008 \\
\hline Oral sucker width & $110-270(209)$ & $200-370(262)$ & -3.93 & 0.0003 \\
\hline Esophagus length & $80-150(113)$ & $80-180(124)$ & -1.17 & 0.24 \\
\hline Esophagus width & $40-60(43)$ & $30-50(39)$ & 1.04 & 0.3 \\
\hline Acetabulum length & $320-880(595)$ & $400-940(593)$ & 0.03 & 0.97 \\
\hline Acetabulum width & $350-800(592)$ & $450-900(604)$ & -0.30 & 0.75 \\
\hline Anterior testis width & $150-300(214)$ & $100-300(242)$ & -1.69 & 0.09 \\
\hline Posterior testis length & $250-980(553)$ & $90-800(496)$ & 1.10 & 0.28 \\
\hline Posterior testis width & $150-300(201)$ & $100-390(243)$ & -2.18 & 0.04 \\
\hline Seminal vesicle length & $50-240(119)$ & $80-230(152)$ & -2.74 & 0.009 \\
\hline Seminal vesicle width & $50-190(93)$ & 50-190 (111) & -1.61 & 0.11 \\
\hline Ovary length & $120-330(277)$ & $200-400(284)$ & -0.40 & 0.69 \\
\hline Ovary width & $100-230(165)$ & $130-260(193)$ & -2.61 & 0.01 \\
\hline Vitellaria, number and shape & 2 kidney-shape lobed & 2 kidney-shape lobed & - & - \\
\hline Uterus & $\begin{array}{l}\text { Sinuous; filling available } \\
\text { space posterior to ovary }\end{array}$ & $\begin{array}{l}\text { Sinuous; filling available } \\
\text { space posterior to ovary }\end{array}$ & - & - \\
\hline Egg length & $25-33(28)$ & $25-35(29)$ & -1.15 & 0.26 \\
\hline Egg width & $17.5-23(18)$ & $15-23(17.8)$ & 0.93 & 0.36 \\
\hline
\end{tabular}

* Approximate $t_{\mathrm{s}}$-test.

$=44)$ by $100-390 \mu \mathrm{m}(223)$ wide $(\mathrm{n}=42)$. Seminal vesicle oval to round, dorsal to the anterior edge of acetabulum; 50-250 $\mu \mathrm{m}$ (139) long and 50-190 $\mu \mathrm{m}$ (104) wide. Genital pore anterior to ventral sucker, located medially in forebody. Ovary anterior to anterior testis and posterior to vitellaria; sometimes overlaps anterior testis, oval to irregular in shape located on the right or left side of body, 120-430 $\mu \mathrm{m}$ (287) long and 100-320 $\mu \mathrm{m}(187)$ wide $(\mathrm{n}=45)$. Vitellaria 2, compact kidney to oval shape lobed masses; occasionally not compact in some individuals recovered from bullfrogs, immediately posterior to acetabulum on middle line of body. Uterine loops filling postacetabular region and overlapping dorsally, ventrally, and laterally with testes, usually overlap entire posterior testis and partially overlap ovary and vitelline glands in large individuals. Eggs thin shelled and nonoperculated, embryonated, 25-35 $\mu \mathrm{m}$ (29) long, and 15-23 $\mu \mathrm{m}$ (18) wide $(\mathrm{N}=45)$.

\section{Taxonomic summary}

Type host: Rana pipiens Schreber 1782, (Anura: Ranidae).

Other hosts: Rana blairi Mecham, Littlejohn, Oldham, Brown, and Brown, 1973; $R$. catesbeiana Shaw, 1802; $R$. chiricahuensis Platz and Mecham, 1979; $R$. clamitans Latreille in Sonnini de Manoncourt and Latreille, 1801; $R$. dunni Zweifel, 1957; $R$. grylio Stejneger, 1901; $R$. heckscheri Wright, 1924; R. megapoda Taylor, 1942; R. montezumae Baird, 1854; $R$. neovolcanica Hillis and Frost, 1985; $R$. palustris LeConte, 1825; R. septentrionalis Baird, 1854; R. sphenocephala Cope, 1886; R. vaillanti Brocchi, 1877 (Anura: Ranidae); Bufo americanus Holbrook, 1836; B. fowleri Hinckley, 1882; B. woodhousii Girard, 1854 (Anura: Bufonidae); Leptodactylus melanonotus (Hallowell, 1861) (Anura: Leptodactilidae); Notophthalmus viridescens (Rafinesque, 1820) (Caudata: Salamandridae); Ambystoma andersoni Krebs and Brandon,
1984; A. tigrinum (Green, 1825); A. dumerilii (Dugès, 1870); A. lermaense (Taylor, 1940) (Caudata: Ambystomatidae); and Thamnophis sirtalis (Linnaeus, 1758) (Squamata: Serpentes).

Site of infection: Urinary bladder.

Type locality: Cedar Creek, Keith County, Nebraska (R. pipiens; $R$. catesbeiana; B. woodhousii).

Other localities: New Brunswick, Ontario, and Quebec (all in Canada); Arkansas, Arizona, Florida, Georgia, Illinois, Indiana, Iowa, Kansas, Maine, Massachusetts, Minnesota, Michigan, Nebraska, New York, North Carolina, Ohio, Texas, and Wisconsin (all in the United States); Cointzio, Michoacán; Laguna Escondida, Veracruz; Lerma, Mexico State; Mexico City; Sonora; and Zacapus, Michoacán (all in Mexico); Guatemala (see Brooks, 1976; Bolek and Coggins, 2003; ParedesCalderón et al., 2004; King et al., 2008; Bolek et al., 2009).

Neotype: Deposited at the HWML collection (HWML 49008), University of Nebraska State Museum, Lincoln, Nebraska; vouchers of $G$. attenuata from other anurans were deposited in the H.W. Manter Parasitology Collection, University of Nebraska, Lincoln, Nebraska (accession numbers HWML 48984-48998) by Bolek et al. (2009).

\section{Remarks}

The few measurements presented by Stafford (1902) fall within the ranges presented in the redescription; all qualitative features (shape, position of the vitellaria, testes, and ovary) observed in the specimens used in this study were consistent with those articulated by Stafford (1902). Of the 12 North American amphibian bladder flukes in the genus Gorgoderina, G. attenuata, along with G. tanneri Olsen, 1937, and G. aurora Ingles, 1936, form a group of North American Gorgoderina spp. distinguished from the other members of the genus in that 
the acetabulum is approximately twice the length and width of the ora sucker. However, G. tanneri can be distinguished from $G$. attenuata by its regularly lobed vitellaria, with 3-6 lobes with a slender stem versus compact kidney-shaped lobed masses in G. attenuata. Gorgoderina aurora differs from $G$. attenuata by being longer $(5.0-8.0 \mathrm{~mm}$ vs. 1.3 $5.0 \mathrm{~mm})$ and wider $(0.65 \mathrm{~mm}$ vs. $0.40 \mathrm{~mm})$ and having a wider acetabulum (0.65 mm vs. $0.60 \mathrm{~mm})$.

Morphological comparisons between gravid $G$. attenuata recovered from bullfrogs and northern leopard frogs are presented in Table I. Statistically significant differences between worms from bullfrogs and northern leopard frogs existed in body width, forebody length and width, hindbody width, oral sucker length and width, OS/AC width ratio, body width to acetabulum ratio, ovary width, posterior testis width, and seminal vesicle length. Although the differences were sig nificant, there was overlap in the size range of all of these characters.

\section{DISCUSSION}

Stafford (1902) based his original description of G. attenuata on worms recovered from $R$. virescens $(=R$. pipiens?) and indicated (but did not provide any measurements) that worms recovered from $R$. catesbeiana were similar to, but morphologically different from, worms recovered from $R$. virescens. Stafford (1902), Cort (1912), and Goodchild (1950) all indicated that $G$. attenuata recovered from bullfrogs were smaller and differed in the morphology of their testes when compared with worms from northern leopard frogs. Additionally, Goodchild (1950) and Bolek et al. (2009) indicated that gravid G. attenuata recovered from bullfrogs and northern leopard frogs differ in their location in the host (urinary bladder in northern leopard frogs and urinary bladder and kidneys in bullfrogs). Currently, it is unclear whether $G$. attenuata-like worms recovered from bullfrogs and the 22 other hosts reported for this species are morphologically different from worms recovered from northern leopard frogs due to host-induced morphological variability, represent distinct populations, or are cryptic species. Recent life cycle studies on G. attenuata in northern leopard frogs, Woodhouse's toads, and bullfrogs in Nebraska by Bolek et al. (2009) indicate that the life cycle strategies of $G$. attenuata in bullfrogs differ compared with the strategies of G. attenuata worms in northern leopard frogs and Woodhouse's toads, as well as from the original life cycle description of this species in green frogs and eastern newts by Rankin (1939). Based on our morphological study and life cycle studies by Bolek et al. (2009), we suggest that morphological and molecular data from multiple genes from $G$. attenuata-like worms collected from bullfrogs and different populations of the 22 other species of definitive hosts will be necessary to resolve this issue.

\section{ACKNOWLEDGMENTS}

We greatly acknowledge Dr. Agustín Jiménez-Ruiz, HWML of Parasitology, University of Nebraska State Museum for providing specimens of gorgoderids for comparisons. M.G.B. thanks Melissa Bolek for help in collecting anurans; Randy Peterson, Duane Dunwoody, Bill Breen, the Sillisen family, and Dr. Susan Lewis, Carroll College, for access to field sites; Cedar Point Biological Station for providing facilities; and Miloslav Jirků for comments on the manuscript. Additionally, we thank Dr. Kirsten Jensen for helpful comments that dramatically improved this manuscript. This work was supported by grants from the Center for Great Plains Studies graduate student grant-in-aid, University of Nebraska-Lincoln, Initiative for Ecology and Evolutionary Analysis, University of Nebraska-Lincoln, and The School of Biological Sciences, University of Nebraska-Lincoln

\section{LITERATURE CITED}

Bolek, M. G. AND J. R. CogGins. 2003. Helminth community structure of sympatric eastern American toad, Bufo americanus americanus, northern leopard frog, Rana pipiens, and blue-spotted salamander, Ambystoma laterale, from southeastern Wisconsin. Journal of Parasitology 89: 673-680.

, S. D. SNyder, And J. Janovy, JR. 2009. Alternative life cycle strategies and colonization of young anurans by Gorgoderina attenuata in Nebraska. Journal of Parasitology 95: 604-616.

Brooks, D. L. 1976. Parasites of amphibians of the Great Plains: Part 2. Platyhelminths of amphibians in Nebraska. Bulletin of the University of Nebraska State Museum 10: 65-92.

CORT, W. W. 1912. North American frog bladder flukes. Transactions of the American Microscopical Society 31: 151-168.

Frost, D. R., T. Grant, J. Faivovich, R. H. Bain, A. Hass, C. F. B Haddad, R. O. de Sa, A. Channing, M. Wilkinson, S. C. DonNELLAN, ET AL. 2006. The amphibian tree of life. Bulletin of the American Museum of Natural History 297: 1-370.

GoodCHILD, C. G. 1950. Establishment and pathology of gorgoderid infections in anuran kidneys. Journal of Parasitology 36: 439-446.

King, K. C., A. D. Gendron, J. D. Mclaughlin, I. Giroux, P. BrousSeau, D. Cyr, S. M. Ruby, M. Fournier, and D. J. Marcogliese. 2008. Short-term seasonal changes in parasite community structure in northern leopard froglets (Rana pipiens) inhabiting agricultural wetlands. Journal of Parasitology 94: 13-22.

LANNOO, M. 2005. Amphibian declines. The conservation status of United States species. University of California Press, Berkeley, California, 1,094 p.

MATA-López, R. 2006. A new gorgoderid species of the urinary bladder of Rana zweifeli from Michoacán, Mexico. Revista Mexicana de Biodiversidad 77: 191-198.

, L. García-Prieto, AND V. León-RÈgagnon. 2002. Infracomunidades de helmintos parásitos de Ambystoma lermaensis (Caudata: Ambystomatidae) en Lerma, Mexico. Revista de Biología Tropical 50: 303-307.

, AND V. LEÓn-RÈGagnon. 2006. Comparative study of the tegument surface of several species of Gorgoderina Looss, 1902 (Digenea: Gorgoderidae), as revealed by scanning electron microscopy. Comparative Parasitology 73: 24-34.

, AND D. R. BROOKS. 2005. Species of Gorgoderina (Digenea: Gorgoderidae) in Rana vaillanti and Rana cf. forreri (Anura: Ranidae) from Guanacaste, Costa Rica, including a description of a new species. Journal of Parasitology 91: 403-410.

Olsen, O. W. 1937. A new species of bladder fluke, Gorgoderina tanneri (Gorgoderidae: Trematoda), from Rana pretiosa. Journal of Parasitology 23: 499-503.

Paredes-Calderón, L., V. León-Règagnon, and L. García-Prieto. 2004. Helminto infracommunities of Rana vaillanti Brocchi (Anura: Ranidae) in Los Tuxtlas, Veracruz Mexico. Journal of Parasitology 90: 692-696.

RANkIN, J. S. 1939. The life cycle of the frog bladder fluke, Gorgoderina attenuata Stafford, 1902 (Trematoda: Gorgoderidae). American Midland Naturalist 21: 476-488.

Sokal, L. L., And J. F. Rohlf. 1981. Biometry. Second edition. W. H. Freeman and Company, New York, New York, 859 p.

STAFFORD, J. 1902. On the American representatives of Distomum cygonides. Zoologische Jahrbuecher Abteilung fuer Systematik Oekologie und Geographie der Tiere 17: 411-424.

-. 1905. Trematodes from Canadian Vertebrates. Zoologischer Anzeiger 28: 681-694. 